\title{
Contribution of agroforestry to climate change mitigation and livelihoods in Western Kenya
}

\author{
Saskia Reppin - Shem Kuyah $(\mathbb{D} \cdot$ Andreas de Neergaard • Myles Oelofse • \\ Todd S. Rosenstock
}

Received: 14 September 2018/Accepted: 13 March 2019/Published online: 16 March 2019

(C) The Author(s) 2019

\begin{abstract}
We test the hypothesis that agroforestry improves livelihoods and mitigates climate change in smallholder farming systems simultaneously. Data were collected using household surveys and standard biomass assessment approaches using locally relevant allometric equations. Summary statistics and regression analyses reveal linkages between on-farm carbon stocks and farm- and household characteristics. With an average of $4.07 \pm 0.68 \mathrm{Mg} \mathrm{C}^{-1}$ and Shannon diversity index of 3.06 , farm carbon stocks were significantly associated with farm size $(r=0.453$, $p<0.05)$, tree density $(\mathrm{r}=-0.58, p=0.05)$ and the average size of trees on farm $(\mathrm{r}=-0.42, p=0.05)$, but not by Shannon diversity index $(\mathrm{r}=0.36$, $p=0.080)$, species richness $(\mathrm{r}=-0.044, \quad p=$ $0.833)$ or the number of land use categories $(\mathrm{r}=-0.192, p=0.356)$. Timber was considered the most important use of on-farm trees before firewood
\end{abstract}

S. Reppin · A. de Neergaard · M. Oelofse

Department of Plant and Environmental Sciences, Faculty of Science, University of Copenhagen, Thorvaldsensvej

40, 1871 Frederiksberg, Denmark

S. Reppin - T. S. Rosenstock

World Agroforestry Centre (ICRAF),

P.O. Box 30677-00100, UN Avenue, Nairobi, Kenya

S. Kuyah $(\bowtie)$

Department of Botany, Jomo Kenyatta University of

Agriculture and Technology,

P.O. Box 62000-00200, Nairobi, Kenya

e-mail: kuyashem@gmail.com and construction material. The results suggest that gaining self-sufficiency in firewood is the most important benefit with on-farm carbon accumulation. The focus on exotic species for timber production presents a considerable trade-off between livelihood options and environmental goals. Heterogeneity in local environmental conditions over very short distances, less than $12 \mathrm{~km}$, significantly determine livelihood strategies and on-farm carbon stocks. These results ostensibly contradict that carbon storage in smallholder farms is determined by diversity of tree species, suggest that livelihood strategy can equally drive carbon storage and demonstrate the diversity of livelihood and environmental benefits derived from trees on farms.

Keywords Aboveground biomass - Carbon stocks · On-farm trees $\cdot$ Species diversity $\cdot$ Trade-off

\footnotetext{
S. Kuyah

Institute of Crop Sciences and Resource Conservation (INRES) - Horticultural Science, Auf dem Hügel 6, 53121 Bonn, Germany

T. S. Rosenstock

CGIAR Research Program on Climate Change, Agriculture, and Food Security (CCAFS), P.O. Box 30677-00100, UN Avenue, Nairobi, Kenya

A. de Neergaard

Faculty of Social Sciences, University of Copenhagen, Øster Farimagsgade 5, 1353 Copenhagen, Denmark
} 


\section{Introduction}

Climate change may significantly reduce the productivity of farms globally (Harvey et al. 2014). Throughout the tropics, the effects of changes in temperature and precipitation patterns are predicted to be particularly negative with declines of crop yields, increased environmental suitability of agricultural pests and diseases and decreasing livestock pasture (feed) quality (Porter et al. 2014). Potential impact of climate change on farm productivity is a significant concern given that agriculture represents the primary livelihood strategy for the vast majority of rural poor in tropical developing countries; this group typically has limited access to additional financial or biophysical resources to adapt to the predicted less hospitable weather patterns (Morton 2007; Bryan et al. 2013a). While climate change threatens agriculture, it also contributes to events such as increased temperatures described by global warming. Greenhouse gas emissions due to agriculture are estimated to be between 5 and $7 \mathrm{GtCO}_{2}$ /year (Scholes et al. 2014), equivalent to $14 \%$ of the total anthropogenic emissions (IPCC 2014). Agriculture, however, can help mitigate climate change. Agricultural mitigation can be realized through a variety of practices that increase carbon sequestration in soils and biomass (Scholes et al. 2014).

Agroforestry is an often named solution for the dual climate and food security challenges (Dinesh et al. 2017). Agroforestry practices, such as the integration of leguminous trees into fallow periods between two cropping seasons (improved fallow), or intercropping short- and long-term trees with crops (dispersed intercropping), can lead to higher crop yields in many parts of the tropics (Hall et al. 2005), and increased well-being (Thorlakson and Neufeldt 2012). Meanwhile, agroforestry can mitigate climate change through creating and enhancing carbon sinks by capturing carbon from the atmosphere through photosynthesis and storing it in biomass and soil (Albrecht and Kandji 2003). Considering only the tree component of agroforestry systems, estimates based on growth rates and wood production from a limited number of studies show an average carbon stock in agroforestry systems between 9 and $63 \mathrm{Mg} \mathrm{C}$ ha year ${ }^{-1}$ depending on the climate (semi-arid to temperate) (Montagnini and Nair 2004). However, carbon stocks in agroforestry systems of the tropics vary even for similar types of agroforestry systems (Nair and Nair 2014) due to the diversity of agroforestry practices (e.g., homegardens, windbreaks, intercropping, woodlots, etc.) and the impact of environmental (e.g., access to soil moisture, light and nutrients) and management (e.g., pruning and felling) factors suggesting the potential for agroforestry to be a low emission development strategy may be site specific.

The contributions of agroforestry practices to the livelihoods of farmers are determined by local biophysical and socio-economic factors and need to be examined from their perspective (Dumont et al. 2017). The global benefit of regulating climate through carbon sequestration cannot be considered a motivating argument for smallholder farmers to invest in new farming practices (Bryan et al. 2013b). Therefore, mitigation efforts at smallholder farm level need to produce tangible and direct livelihood benefits for farmers, such as being a source of food, fuel or fodder with mitigation being a co-benefit of the improved agricultural practice (Ogle et al. 2014). The majority of studies only quantify either the amount of carbon stocks in smallholder systems (e.g. Henry et al. 2009) or the role of agroforestry in building resilience to climate-related hazards (e.g. Thorlakson and Neufeldt 2012). Further, recent studies assessing carbon stocks often focus on particular agroforestry practices such as natural or planted fallows, agroforestry parkland and rangeland (Marone et al. 2017), or particular species such as coffee agroforestry (Guillemot et al. 2018) or cocoa agroforestry (Middendorp et al. 2018). On the other hand, studies assessing livelihoods rarely monitor carbon stocks, for example Nath et al. (2016) in Western Ghats, India and Quandt et al. (2017) in western Kenya. This study is different from a simple biomass assessment in that it provides additional information about other benefits that farmers obtain from trees. By assessing benefits of on-farm trees from both the climate and farmers' point of view, this study connects carbon stocks, species diversity and agroforestry practices and thereby identifies common householdand farm characteristics that can drive on-farm carbon storage. This leads to a nuanced and locally relevant understanding of farmers' choices and possibilities of how to mitigate climate change and improve livelihoods concurrently.

In this study, we applied a mixed method approach to quantify carbon stocks and livelihoods benefits of 


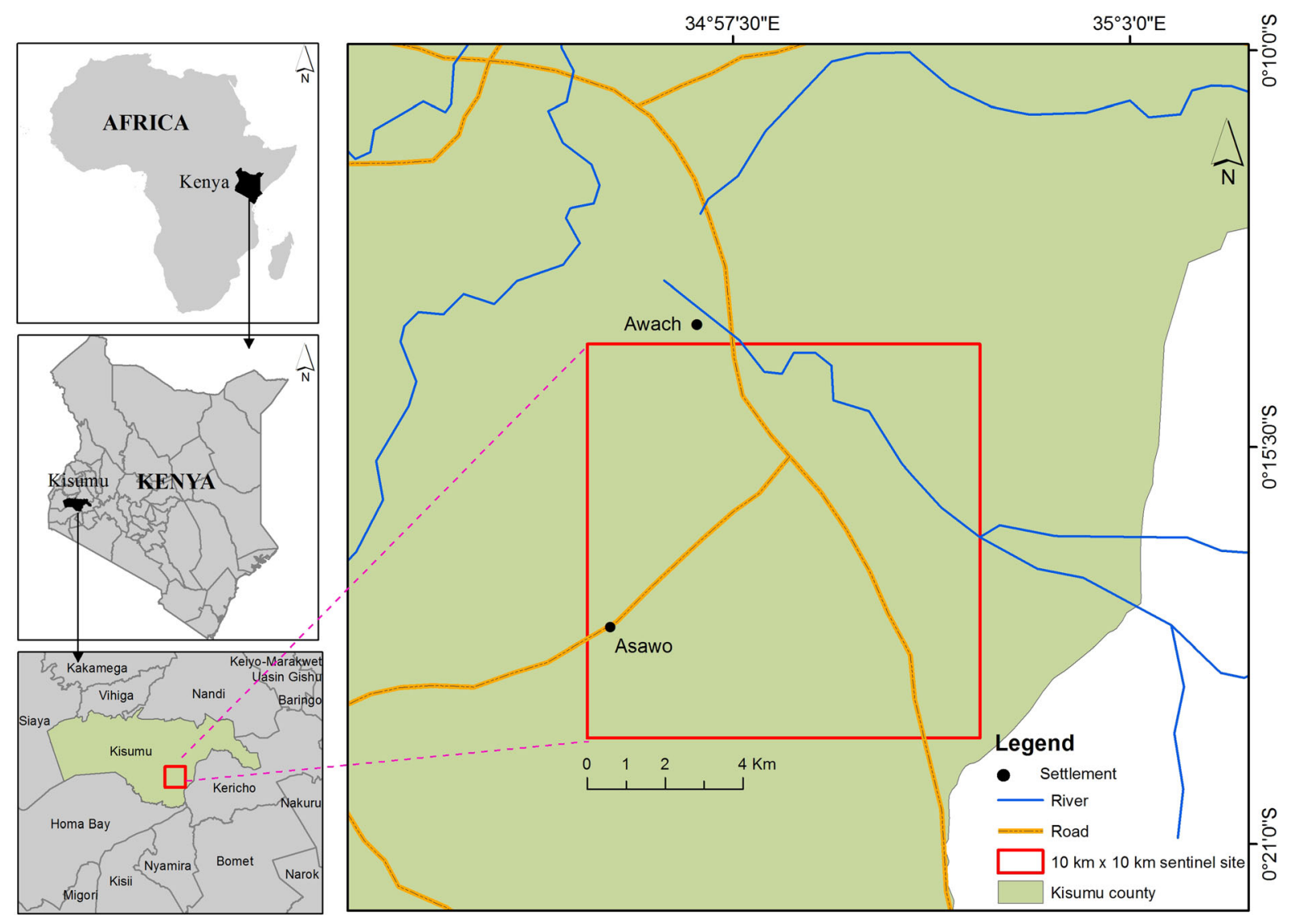

Fig. 1 Location of the study site within the Nyando River basin in Kisumu County, western Kenya

trees on smallholder farms in Western Kenya. Our hypotheses were (1) the land use type, on-farm tree diversity and farm size drive the amount of aboveground biomass carbon on smallholder farms, (2) onfarm trees in smallholder farming systems provide an important contribution to livelihoods, and (3) household- and farm demographic and socio-economic characteristics explain carbon stocks on smallholder farms.

\section{Materials and methods}

Study site

The study site is located in Kisumu County, formerly Nyanza Province, Western Kenya. The sampled farms lie within the CGIAR Research Program on Climate Change, Agriculture, and Food Security (CCAFS) 'Lower Nyando' benchmark site, a $10 \mathrm{~km} \times 10 \mathrm{~km}$ research site situated in the Nyando River Basin (Fig. 1). The climate in the Nyando River basin varies from semi-arid to sub-humid. Precipitation falls in a bimodial pattern with a cumulative annual average of $1000 \mathrm{~mm}$; long rains occur between March and May, while short rains occur between October and November (Boye et al. 2008). The mean annual minimum and the maximum temperature ranges between $12-16{ }^{\circ} \mathrm{C}$ and $29-31{ }^{\circ} \mathrm{C}$. Elevation ranges between 1170 and $1750 \mathrm{~m}$ above sea level (Boye et al. 2008). Topography varies with slopes ranging between $1.1 \%$ in the lowland in the Southern part of the site to $9.6 \%$ in the Northern areas. The dominant soil types in Lower Nyando are Luvisols and Gleysols (Boye et al. 2008).

Nyando is densely populated, with over 250 people per $\mathrm{km}^{2}$. Farms operate three major types of farming systems whose distribution is determined by topography and micro-climates in highlands, mid-slope, and lowland areas. In all systems, cereal crops, livestock, and fuel wood production play an important role as a 
livelihood source for consumption and commercialization (Mango et al. 2011). Maize, sorghum and beans are the major field crops grown in Lower Nyando (Mango et al. 2011). Fruit trees common in the area include Mangifera indica (mango), Musa spp. (banana) and Psidium guajava (guava). Livestock production entails mixtures of indigenous and crossbred cattle raised under free range or semi zerograzing systems. The higher elevated areas have dense vegetation with sparse settlements. Besides food (maize) and cash (tea) crops, perennial grasses, including Napier grass make up the dominant vegetation in higher elevated areas. The mid-slope area is characterized by lower population density, slightly larger farm sizes with sugarcane production and crossbred livestock. In the lowlands, agricultural production uses local breeds of free-grazing cattle, sorghum and maize.

\section{Farm selection}

Farms surveyed in this study were a subset of 200 households previously selected and surveyed for household assets and farming system (Rufino et al. 2012). We used a two-step process to select the households to sample. First, a cluster analysis of the 200 households based on altitude, farming systems and environmental resource use patterns was conducted and 60 households randomly selected (20 per farming system). Second, 28 households were then randomly selected from the 60 sampled households for tree inventory and biomass assessment. Random selection of the households eliminated the likelihood of convenience sampling and allowed to capture the typical mix of plant species, livelihood strategies and farming systems in the area. Two farms were removed from the sample since they were commercial largescale operations and thus did not meet study objectives of sampling smallholder farming systems $(<2 \mathrm{ha})$; therefore, the biomass assessment was based on 26 farms.

Tree inventory and biomass assessment

Tree inventory and biomass assessment was conducted for the 26 selected farms by recording species names, diameter at breast height (DBH) of trees, and farm characteristics. Total farm size, tree size and location and land use type were mapped by GPS tracking (eTrex Legend and Oregon 600, Garmin). A total of six land use categories were identified for the analysis; each individual tree was assigned to one of the eight land use types as follows. (1) Homestead: Trees (mostly shade- or fruit trees) scattered within the area around the house, occasionally including animal shelter but no cropland. It also includes trees planted along the boundary of the compound with protective and aesthetic purpose. (2) Cropland: Trees scattered within land for crop production. (3) Grazing area: Trees scattered in fields used for grazing livestock. (4) Boundary: Trees planted along the outer boundary of the entire farms for demarcation and protection, as well as rows of trees separating different land use categories within the farm. (5) Shrub land: Trees within land that is unmanaged and covered with bushes and shrubs, sometimes used to let goats browse. (6) Woodlot: Area with trees planted in high density, mostly monocultures, mainly for timber and fuelwood production.

For all trees within each land use in the farm, aboveground biomass was assessed by non-destructive methods consistent with guidelines used in smallholder systems (Rosenstock et al. 2013; Kuyah and Rosenstock 2015). DBH was measured at a height of $1.3 \mathrm{~m}$ above the ground level and over-bark. The stems of trees forking below $1.3 \mathrm{~m}$ were measured separately and identified as multi-stemmed trees. DBH of multi-stemmed trees was calculated as the square root of the sum of squares of diameter measurements of individual stems. Trees that forked just above the ground were measured separately and identified as separate trees. When trees had dead or missing branches just above breast height, DBH was measured above the missing branch. On heavily deformed stems, the clearest and smoothest point for measuring DBH was selected right above or below $1.3 \mathrm{~m}$. The species name of all measured trees was also recorded. Only living trees with a diameter greater than $2.5 \mathrm{~cm}(8 \mathrm{~cm}$ circumference) found on farmers' owned land were measured.

Household survey

A survey was designed to collect information about household uses and benefits of on-farm trees and their role as a livelihood source in terms of household consumption and commercialization. The survey consisted mainly of open-ended qualitative questions 
administered to the random sample of 60 households. One member of the selected household was interviewed, among others, about the tree species in their farm and their uses and benefits. The survey was conducted in November 2014 by trained enumerators in two local languages.

\section{Data analysis}

Biomass and carbon stocks were calculated for each farm and for each land use category. A two-step approach was used to determine allometric equations appropriate for trees measured. First, species-specific and relevant general allometric equations were identified from literature for species that contributed most individuals (above $0.5 \%$ ) to the total number of trees recorded ("Appendix 1"). Species-specific equations were only considered if they were: (1) developed from at least 30 destructively sampled trees spanning diameter-range covered by individuals of the species of interest, (2) power-law function with diameter-only as the predictor variable, and (3) developed from trees sampled from agricultural landscapes, excluding plantations or natural ecosystems. General allometric equations were required to meet the second criteria and to have been developed with data that include species that contributed most individuals recorded in Lower Nyando. Second, appropriateness of allometric equations that met this criteria i.e. species-specific equations for Eucalyptus spp. and Acacia spp. (Paul et al. 2013) and the general equations reported by FAO (Brown 1997) was determined by calculating the relative error (\%) between predicted and actual biomass of species of interest using a dataset of trees harvested in western Kenya (Kuyah et al. 2012, 2013). Relative errors for validated species-specific and general equation are presented in "Appendix 2". Guidelines for selecting appropriate equations were applied (Sileshi 2014; Kuyah and Rosenstock 2015).

Equation 1 (Kuyah et al. 2012) was used to convert DBH to aboveground biomass, being the most regionally and climate-relevant multi-species allometric equation for trees in agricultural landscapes in western Kenya.

$\mathrm{AGB}=0.0905 \times \mathrm{DBH}^{2.4718}$

Biomass estimates obtained were converted to carbon stocks using the default carbon fraction value of 0.47 from Intergovernmental Panel on Climate Change (IPCC 2006). Aboveground carbon stocks of trees within the same land use in the farm were divided by the area of the land use type to obtain land use level carbon stocks. Aboveground carbon stock at farm level was obtained by summing carbon stocks of all the trees in the entire farm divided by farm size. For trees on farm boundary and those separating different land use within farms, the length of the boundary and a width of $2 \mathrm{~m}$ was used to calculate carbon stocks per unit area. Each measured tree was identified with its species name (scientific and local) and categorized into one of the identified land use type. A complete list of recorded tree species with local and scientific names can be found in "Appendix 1".

The Shannon Index $\left(\mathrm{H}^{\prime}\right)$ was used to describe tree diversity across the study area, for the farms and land use type using Eq. 2:

$H^{\prime}=-\sum_{i=1}^{s} p_{i} \ln p_{i}$

where $p$ is the proportion $(\mathrm{n} / \mathrm{N})$ of individuals of a particular species $(n)$ divided by the total number of individuals $(N), \ln$ is the natural $\log , \Sigma$ is the sum of the calculations, and $s$ is the number of species. Shannon diversity index considers species richness (total number of different species), tree abundance (total number of trees) and the relative species abundance or evenness (count of trees for each species). Chao, Bootstrap and first and second order Jackknife prediction methods were applied with BiodiversityR (Kindt and Coe 2005) to extrapolate total species richness, to estimate what proportion of the total species richness was captured in the sample.

Descriptive statistics were applied to analyse household survey data to reveal the uses and benefits of different tree species. Correlations between farm level carbon stocks and a subset biophysical farm and socio-economic household characteristics were conducted with a significance level of $95 \%$ to examine relationships between carbon stocks and household and farm characteristics. Multiple linear regression analysis was used to identify the strength of the effects of farm characteristics on farm level carbon. Associations (Kruskal-Walis, Mann-Whitney and Chi square) and differences between groups (analysis of variance: ANOVA) of various farm- and household characteristics were tested for significance $(p<0.05)$. 
Table 1 Stand structure, composition and diversity of tree species and carbon stocks for different land use type within households surveyed

\begin{tabular}{|c|c|c|c|c|c|c|c|c|c|c|c|}
\hline \multirow[t]{2}{*}{$\begin{array}{l}\text { Farm/land } \\
\text { use }\end{array}$} & \multirow[t]{2}{*}{$\begin{array}{l}\text { House- } \\
\text { holds }\end{array}$} & \multirow[t]{2}{*}{$\begin{array}{l}\text { Area } \\
\text { (ha) }\end{array}$} & \multirow[t]{2}{*}{$\begin{array}{l}\text { Tree } \\
\text { density }\end{array}$} & \multirow[t]{2}{*}{$\begin{array}{l}\text { Mean DBH } \\
(\mathrm{cm})\end{array}$} & \multicolumn{3}{|c|}{ Species richness } & \multicolumn{2}{|c|}{$\begin{array}{l}\text { Composition } \\
(\%)\end{array}$} & \multirow[t]{2}{*}{$\begin{array}{l}\text { Shannon } \\
\text { index }\end{array}$} & \multirow[t]{2}{*}{$\begin{array}{l}\text { AGC (Mg C } \\
\left.\mathrm{ha}^{-1}\right)\end{array}$} \\
\hline & & & & & Overall & Exotic & Native & Exotic & Native & & \\
\hline Farm & 26 & 34.94 & 249 & $7.1 \pm 0.1$ & 83 & 31 & 52 & 48.7 & 51.3 & 3.06 & $4.07 \pm 0.68$ \\
\hline Boundary & 25 & 1.29 & 2211 & $7.3 \pm 0.1$ & 59 & 22 & 37 & 48.4 & 51.6 & 2.90 & $31.13 \pm 5.85$ \\
\hline Cropland & 16 & 9.98 & 57 & $9.3 \pm 0.3$ & 43 & 17 & 26 & 48.0 & 51.5 & 3.12 & $6.36 \pm 4.35$ \\
\hline $\begin{array}{l}\text { Grazing } \\
\text { land }\end{array}$ & 12 & 8.61 & 190 & $5.9 \pm 0.1$ & 37 & 12 & 25 & 19.8 & 80.2 & 2.13 & $2.08 \pm 0.59$ \\
\hline Homestead & 24 & 3.41 & 518 & $8.5 \pm 0.2$ & 61 & 28 & 33 & 46.9 & 53.1 & 3.34 & $51.94 \pm 40.65$ \\
\hline Shrub land & 4 & 0.65 & 448 & $5.5 \pm 0.2$ & 17 & 4 & 14 & 4.1 & 95.9 & 2.20 & $3.17 \pm 2.226$ \\
\hline Woodlot & 9 & 0.56 & 2835 & $6.8 \pm 0.1$ & 24 & 11 & 13 & 89.5 & 10.5 & 1.19 & $39.40 \pm 10.92$ \\
\hline
\end{tabular}

Tree density represents number of trees per ha. Values for diameter at breast height (DBH) and aboveground carbon (AGC) represent means and the standard error of the mean (SE). Species composition represents the percentage of individual trees of native or exotic origin

Prior to the analyses, we verified the data met assumptions of statistical models being used. Statistical analyses were conducted using SPSS 21 (IBM Corp 2011).

\section{Results}

On-farm trees and aboveground carbon stocks

A total of 8712 trees belonging to 83 tree and shrub species were inventoried in 26 farms with a total area of 34.94 ha; average farm size was $1.34 \pm 1.09$ ha (Table 1). An additional 48 individuals belonging to Carica papaya and 170 individuals of unknown identity were also documented. Individuals of Carica papaya and unknown species were not included in diversity analysis or estimation of biomass. About $51 \%$ of trees inventoried were native; the rest were exotic. In terms of abundance, Eucalyptus spp., Euphorbia tirucalli, Acacia spp., G. robusta and Balanites aegyptiaca accounted for 21.2., 9.6, 7.6, 6.3 and $5.0 \%$, respectively of the total number of trees found in Lower Nyando ("Appendix 1"). These five most dominant species accounted for about half of the trees documented. Thirty-eight rare species (those with less than 10 individuals per species) formed $1.5 \%$ of the trees recorded. Most of the rare species $(25$ species) were native to Africa while 13 were of exotic origin. Eucalyptus spp. was mainly planted in woodlots; Acacia spp. was mainly found in grazing fields while E. tirucalli and G. robusta were mainly found on boundary.

The land use type with the richest species diversity were homestead (61 species) and boundary (59 species) (Table 1). The lowest species richness was found in shrub land and woodlots, which were characterised by monospecific stands. A converse trend was observed for tree density, being highest for trees planted in boundaries and in woodlots (2211-2835 trees $\mathrm{ha}^{-1}$ ) compared to other land use types, where tree density ranged from 57 to 518 tree $\mathrm{ha}^{-1}$ (Table 1). Shannon diversity index for the entire study area was 3.06 (Table 1) with an average $\mathrm{H}^{\prime}$ of $1.65 \pm 0.09$ per farm. The value of $\mathrm{H}^{\prime}$ varied across different land uses, being highest for tree populations in homestead and cropland, and lowest in woodlots (Table 1). According to the Bootstrap, Chao and Jackknife I and II species richness prediction method, the tree inventory captured between 61 and $84 \%$ of the tree species richness in the study area.

Trees in Lower Nyando were estimated to store an average of $4.07 \pm 0.68 \mathrm{Mg} \mathrm{C} \mathrm{ha}^{-1}$ per farm (Table 1). Total carbon stored in aboveground biomass within the 26 farms (34.94-ha) sampled was $105 \mathrm{Mg} \mathrm{C} \mathrm{ha}{ }^{-1}$. This amount is indicative of the carbon that can be lost if the farmland trees are cleared or die and decompose. Large trees (with DBH above $30 \mathrm{~cm}$ ) were few in Lower Nyando, representing only $5 \%$ of the trees inventoried but over half $(51 \%)$ of the 
Fig. 2 Aboveground farm carbon as function of a farm size and $\mathbf{b}$ Shannon diversity index (a)

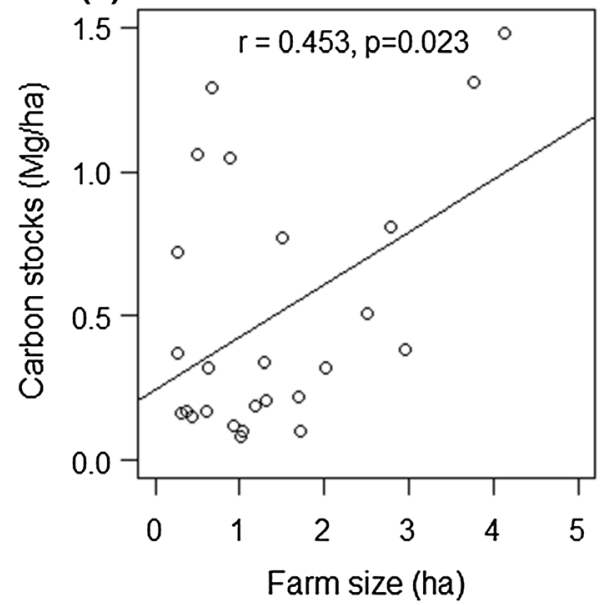

(b)

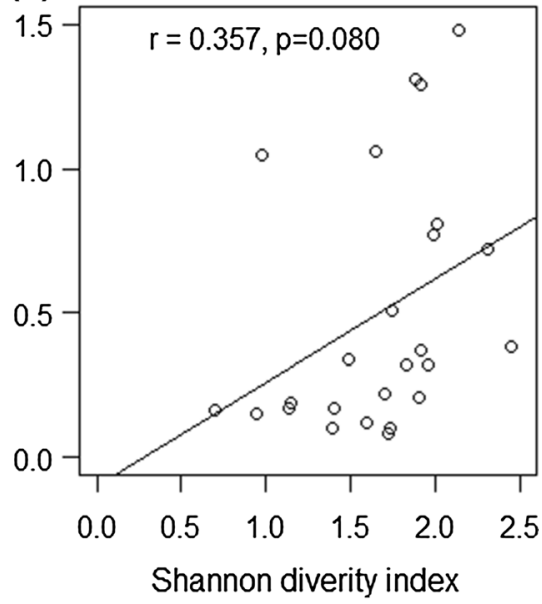

carbon stocks. Larger trees were mainly concentrated in homesteads and boundaries. Eighty percent $(80 \%)$ of all trees inventoried had a DBH less than $10 \mathrm{~cm}$ and held about $16 \%$ of the total carbon. The mean carbon stocks per farm was $2.2 \pm 2.2 \mathrm{Mg} \mathrm{C}^{-1}$ for exotic trees and $3.2 \pm 1.6 \mathrm{Mg} \mathrm{C}^{-1}$ for native tree species. Carbon stocks within the farm differed among the land use types, being largest in homestead and lowest in shrub land and cropland (Table 1). Summing the average contributions of each land use, homestead $(37.6 \%)$, woodlots $(28.5 \%)$ and boundaries $(22.5 \%)$ accounted for over $88.6 \%$ of the total carbon found in the farms.

Mean carbon stocks per farm had a significant positive correlation with farm size (Fig. 2). There was a moderate and non-significant positive correlation between carbon stocks and the Shannon Index $(\mathrm{r}=0.451, p=0.080)$. However, the relationship between farm carbon and species richness was weak, negative and not significant $(\mathrm{r}=-0.044, p=0.833)$. A weak negative correlation was found between farm level carbon stocks and the number of retained tree species $(\mathrm{r}=-0.261, p=0.198)$, the number of land use types $(\mathrm{r}=-0.002, p=0.993)$, and the number of benefits or uses of trees $(\mathrm{r}=-0.001, p=0$. 632). There was, however, a moderate negative and significant association between farm level carbon stocks and tree density $(-0.582, p<0.05)$ as well as average size of trees on the farm $(\mathrm{r}=-0.420, p=0.05)$. No significant correlations were evident between carbon stocks and the measured socio-economic variables: off-farm income, household size, and access to off- farm products. A negative (non-significant) correlation was evident between the total number of ruminant livestock and carbon stocks ( $\mathrm{r}=-0.344, p=0.085)$. However, ruminant number correlated significantly with tree use $(r=-0.495, p<0.05)$, number of exotic species $(\mathrm{r}=0.439, p<0.05)$ and the number of timber trees $(r=0.432, p<0.05)$. There was a significant relationship between farms with a woodlot and their firewood self-sufficiency (Fisher's extract $p=0.009, \mathrm{n}=26$ ). Seventy-eight percent of the farms with a woodlot were also self-sufficient in firewood while $82 \%$ of the farms without a woodlot were not self-sufficient in firewood.

Household uses of trees

A total of 18 uses and benefits of on-farm trees were documented for 68 tree species mentioned by farmers in Lower Nyando (Fig. 3). Trees provided benefits for household consumption and for sale. The most frequently mentioned use of trees was firewood, followed by construction material, shade, fruit and timber (Fig. 3). The bulk of these benefits were provided by Eucalyptus spp., G. robusta, Vepris nobilis, and Terminalia brownii (Table 2). Respondents ranked timber, firewood, construction material, fruits and shade as the foremost important benefits. Ten percent of the households mentioned other uses, such as aesthetic value, scent of trees, boundary demarcation, seedlings and food. On average each household extracted five (range between 1 and 9) unique benefits from all on-farm trees. A complete list 
Fig. 3 Common uses and benefits of trees. Green columns indicate proportion of total statements on use of trees for that purpose. Orange diamond indicates number of tree species associated with that use. As implication, diamonds above averaged trend-line suggest many species are used for that purpose, while diamonds below trend line, indicate specific trees for that use (more narrow selection of species). (Color figure online)

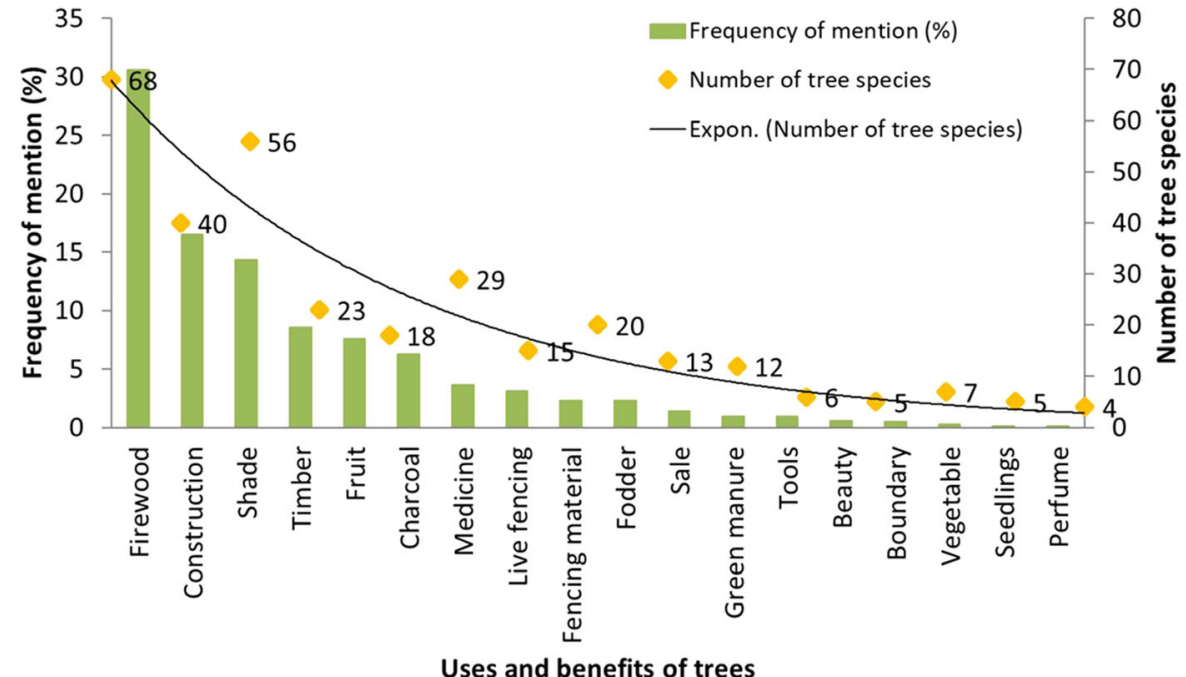

Uses and benefits of trees

Table 2 Farmers most frequently mentioned tree species $(n=60)$, their measured abundance per farm $(n=26)($ mean \pm SD), their use variety and the three most frequently mentioned uses for each species, represented in a minimum of $20 \%$ of the households

\begin{tabular}{|c|c|c|c|c|}
\hline No. of households & Tree species & Abundance & Use variety & Main uses \\
\hline 40 & Eucalyptus saligna (ex.) & $106 \pm 248 * *$ & 10 & FW, CM, Ti \\
\hline 34 & Grevillea robusta (ex.) & $21.2 \pm 60.1$ & 9 & FW, Ti, CM \\
\hline 29 & Terminalia brownii (nat.) & $15 \pm 26.5$ & 10 & FW, CM, Ti \\
\hline 24 & Vepris nobilis (nat.) & $9.3 \pm 16.2$ & 10 & $\mathrm{FW}, \mathrm{CM}, \mathrm{Ch}$ \\
\hline 20 & Markhamia lutea (nat.) & $8.5 \pm 15.2$ & 7 & $\mathrm{FW}, \mathrm{CM}, \mathrm{Ch}$ \\
\hline 16 & Mangifera indica $(\text { ex. })^{*}$ & $2.2 \pm 6.7$ & 3 & Fr, FW, Sh \\
\hline 16 & Croton megalocarpus (nat.) & $3.2 \pm 8.8$ & 6 & $\mathrm{FW}, \mathrm{Sh}, \mathrm{CM}$ \\
\hline 15 & Persea americana (ex.)* & $1.7 \pm 3.4$ & 6 & Fr, FW, Sh \\
\hline 15 & Thevetia peruviana (ex.) & $14.8 \pm 43.8$ & 6 & FW, Sh, CM \\
\hline 14 & Euclea divinorum (nat.) & $14.1 \pm 55.8$ & 8 & $\mathrm{FW}, \mathrm{Ch}, \mathrm{Sh}$ \\
\hline 14 & Rhus vulgaris (nat.) & $14.8 \pm 31.1$ & 9 & $\mathrm{FW}, \mathrm{CM}, \mathrm{Fr}$ \\
\hline 13 & Psidium guajava (ex.)* & $5 \pm 9.5$ & 6 & Fr, FW, Sh \\
\hline 13 & Acacia spp. (nat.) & $32 \pm 105$ & 5 & FW, FM, CM \\
\hline 12 & Cupressus lusitanica (ex.) & $13.7 \pm 38.7$ & 8 & $\mathrm{CM}, \mathrm{FW}, \mathrm{Ti}$ \\
\hline 12 & Casuarina equisetifolia (ex.) & $1.9 \pm 5.9$ & 8 & $\mathrm{FW}, \mathrm{CM}+\mathrm{Sh}$ \\
\hline
\end{tabular}

$F W$ firewood, $C M$ construction material, $T i$ timber, $C h$ charcoal, $F r$ fruit, $S h$ shade, $F M$ fencing material

*Fruit tree species

**Extrapolated abundance

of most frequently mentioned uses and benefits of trees is presented in "Appendix 3". There was a significant positive correlation between the mean uses and the absolute number of fruit trees per farm ( $\mathrm{r}=0.401, p<0.05)$, and between uses and the number of timber trees $(r=0.425, p<0.05)$.
Trees were planted by the farmer, grown without farmer intervention, or deliberately retained in the farms. Fifty-four percent of all trees surveyed were planted by the farmer, $39 \%$ were retained, and data were not available for the seven percent. The majority of retained on-farm trees were native (77\%), while the majority of planted on-farm trees were exotic $(76 \%)$. 
There was a significant positive correlation $(r=0.71$, $p<0.01$ ) between the number of planted species and the number of exotic trees per farm, however no correlation was found between the number of planted species and the number of native trees. Eucalyptus (E. camaldulensis, E. Saligna and E. grandis) and G. robusta are the two most frequently planted tree species and also the two most frequently mentioned species in the entire study area. Fruit tree species $(M$. indica, Persea americana) are mainly planted, except $P$. guajava, which was mostly retained, as it tends to grow wildly in bush- and shrub land. G. robusta, Eucalyptus spp., Cupressus lusitanica, M. indica, Citrus sinensis and P. americana were cited as the six most preferred additional tree species that farmers would like to have on the farm. These species are desired because they grow fast and are tolerant to pests and diseases (G. robusta and Eucalyptus), have good quality of timber (C. lusitanica), and can improve soil fertility (G. robusta). The main purpose of timber production is to generate income and/or provide construction material for the household. Calliandra calothyrsus and Leucaena leucocephala were preferred for fodder while Terminalia mantaly was preferred for aesthetics and shade.

There was a significant difference in farm elevation between farmers that stated different uses as most important for the 60 survey households $(p=0.008$, $\mathrm{n}=60$ ). Households on higher elevation farms reported the sale of whole trees $($ mean $=1643 \mathrm{~m}$ ) and timber $($ mean $=1486 \mathrm{~m})$ as most important, while households in lower elevation areas stated windbreak $($ mean $=1251 \mathrm{~m})$ and construction material (mean $=$ $1320 \mathrm{~m})$ as most important. Farms that stated firewood as most important had a mean farm elevation of $1475 \mathrm{~m}$. Moreover, there was a difference in the number of retained species on farm $(p=0.042$, $\mathrm{n}=60$ ). Farms that stated firewood as the most important use have on average seven retained species. Farmers stating timber as most important have on average two retained species.

Tree products that cannot be obtained from the own farm were sourced off-farm. These are either bought in formal or in informal markets (e.g., from neighbours) or collected freely from nearby bush lands. Over onethird $(38.3 \%)$ of all households access two products off-farm, more than half $(52 \%)$ of all households access one product and $3.3 \%$ of all households access three products. Fruits were the major product accessed off-farm and were both collected and bought from a market. Other products that were purchased include construction material, timber, seedlings, leaves of sisal (Agave sisalana) plant, furniture and wood for charcoal. Medicine was mainly collected from the wild. Women were mainly responsible for acquiring fruits off-farm while men sourced construction material and timber. The number of use and off-farm products were negatively correlated $(\mathrm{r}=-0.256, \quad p=0.048$, $n=60$ ). Forty percent of households were self-sufficient in firewood, which means they meet household fuelwood consumption from their own farm and do not access firewood off-farm. Forty-three percent of the households collected firewood and $17 \%$ buy from offfarm. There were significant differences between means of uses of trees between households that were firewood self-sufficient and those that were not $(p<0.01, \mathrm{n}=60)$. Firewood self-sufficient households average seven uses of trees while those that are not had only five. Most of the farms that were firewood self-sufficient were located on higher elevations $($ mean $=1509 \mathrm{~m})$ while farms without firewood selfsufficiency were located in lower areas (mean $=1358$ $\mathrm{m})$. In total, 68 different tree species were cited as a source of firewood. Yet, there was a low abundance of fruit trees; three fruit tree species (M. indica, $P$. americana, $P$. guajava) were represented among the 15 most frequently mentioned species.

\section{Discussion}

On-farm trees and carbon stocks

Tree species diversity on the farms in Lower Nyando was high, attributed to a long history of agroforestry in the area (Scherr 1995) and a series of agroforestry development projects (Thorlakson and Neufeldt 2012). Smallholder farmers in western Kenya have a long standing practice of maintaining trees on farms in diverse formations (Bradley 1988). Shannon diversity index in this study $\left(\mathrm{H}^{\prime}=3.06\right)$ was greater than 2.0, which indicates high diversity (Magurran 2004). This value was higher than $\mathrm{H}^{\prime}=0.62$ and $\mathrm{H}^{\prime}=0.50$ determined for Siaya and Vihiga in western Kenya (Henry et al. 2009). Tree species richness of the area (83 species) was higher than 56 and 76 species reported by other studies in western Kenya (Henry et al. 2009; Kuyah et al. 2012). The variety of trees 
species documented underscore the potential of agroforestry to enhance resilience of smallholders to present and future climate risks. For example, farmers in eastern and central Kenya maintain a variety of fodder tree and shrub species to provide livestock feed during the dry season (Gachuiri et al. 2017), while majority of trees and shrub species maintained on farms in the Sahel support soil and water conservation (Faye et al. 2011).

The frequency of distribution of tree species on different land use types was variable. Higher tree species diversity was specially observed in homestead and cropland, where multipurpose trees are grown; woodlots had lower species diversity, featuring single species grown e.g. for timber. Tree species dominated the landscape based on use group, similar to patterns observed in previous surveys in western Kenya, for example high frequencies of Eucalyptus in woodlots, $M$. indica, $P$. americana and $P$. guajava in the homestead area, and $C$. lusitanica on boundaries (Bradley 1988; Kindt et al. 2006). Thus, tree species with higher economic value were widely spread across farms in Lower Nyando. A decrease in on-farm tree diversity through monoculture woodlots that were dominated by Eucalyptus can be considered as an important trade-off with carbon storage in climate change mitigation on smallholder farms. Nevertheless, the plantations of fast-growing timber species are important to achieve firewood self-sufficiency and to generate cash income. Self-sufficiency in firewood supply also can prevent the danger of deforestation of off-farm land or nearby forests (Iiyama et al. 2014). In fact, firewood self-sufficiency can be considered as the most prominent co-benefit with on-farm carbon stocks, and it can be obtained from almost all tree species from various land use types.

Carbon stocks on farms in this region of Kenya average $4.07 \pm 0.68 \mathrm{Mg} \mathrm{C}^{-1}$. These estimates are in the range of aboveground carbon stocks of tropical agroforestry systems in Africa, $1.0-18 \mathrm{Mg} \mathrm{C} \mathrm{ha}^{-1}$ (Nair and Nair 2014), and comparable to average aboveground carbon stocks of $4.9 \pm 1.2 \mathrm{Mg} \mathrm{C}^{-1}$ per farm (based on land use units where trees were inventoried) found in Siaya, Western Kenya (Henry et al. 2009). However, these stocks are less than that measured for the total aboveground carbon in perennial vegetation and in another site (Vihiga), where carbon stocks average $9-11 \mathrm{Mg} \mathrm{C}^{-1}$ per farm (Henry et al. 2009). First, the difference may be attributed to the method of quantification; Henry et al. (2009) determined aboveground carbon using allometric equations developed from 26 individual trees of 5-32 cm DBH, which is a fairly small sample size and size range (Kuyah and Rosenstock 2015) given the variable structure and composition of trees in Lower Nyando. Previous studies show that estimates of carbon stocks can be greatly biased by the choice of allometric equation (Kuyah et al. 2012, 2014). We consider carbon stocks determined in this study as best estimates because of the appropriateness of the equation used. Second, the difference can be attributed to the carbon pools involved in the accounting. Here, we focused only on aboveground tree carbon while Henry et al. (2009) measured perennial shrubs, food and cash crops such as tea plantations and banana plants, and grassland stands. Food crops and pasture accounted for 15.1 and $18.5 \%$ of total farm-level carbon in Siaya and Vihiga, respectively in that study. Assuming the same proportions for these unmeasured pools, carbon stocks at the farms in Lower Nyando would have been more similar, but still lower likely due to the more extensive systems often found in Western Kenya versus the more intensive systems in Central Kenya. A time series assessment of carbon stocks for that range of environment is required to also reveal temporal heterogeneity in carbon stocks; whether agroforestry has helped maintain or increase stored carbon.

The effect of land use type was significant on carbon stocks at the farm level $(p<0.05)$. Over $80 \%$ of aboveground carbon was found (collectively) in homestead, boundary, and woodlots, corresponding to higher tree density and the presence of large trees $(\mathrm{DBH}>30 \mathrm{~cm})$ in these land use types. Similar findings have been reported in western Kenya (Henry et al. 2009) and west African Sahel (Takimoto et al. 2008), where woodlots with mature trees stock higher carbon compared to other land use types within the farm. In agricultural landscapes, land use types with larger trees or higher number of trees often stock larger amount of carbon stocks than those without larger trees or with fewer number of trees (Kuyah et al. 2012, 2014). This suggests that anthropogenic activities with adverse effects on trees have significant implications on aboveground carbon stocks. For example, woodlots store considerable amount of carbon, however, trees in woodlots are harvested after a certain time-period. The stored carbon can be 
released back into the atmosphere when harvested trees are used e.g. for fuelwood. Carbon storage can be prolonged by conversion of the harvested wood into durable products (IPCC 2006). It is therefore important to evaluate management practices of different land use types, as this influence the potential for longterm carbon storage. For example, the trees on boundaries and homestead are retained on farm for demarcation of boundary, protection, aesthetics, fruits and shade; they are sometimes pruned for firewood, but rarely cut down. The oldest and largest trees in the study area were mango trees, similar to results from Salima in Malawi, where mangoes are allowed to increase in size and number on crop farms because of sale and consumption (Kuyah et al. 2014). It therefore implies that coupling climate change mitigation with food security or livelihood objectives can support a long-term carbon storage. Farm size was a determinant of carbon stocks, which means farmers with larger landholdings can store more carbon per unit area than farmers with smaller landholdings. This is because larger farms are likely to have more land use types dedicated to trees compared to small farms where trees are restricted to the homestead or long boundaries. The shrinking farm sizes in the area can therefore lead to decreases in farm carbon stocks, although we do not have a time-dynamic in our data set. Consistent with previous results, species richness was found to have no significant correlation with carbon stocks (Henry et al. 2009). This supports the idea that changes in carbon stock does not always depend upon diversification of species. As such, measures to enhance carbon stocks through agroforestry cannot assure biodiversity conservation, and therefore programs aimed at carbon enhancement should include an objective on promotion of biodiversity.

\section{Livelihood benefits of trees}

Trees on smallholder farms in western Kenya are generally in high demand and serve specific purposes. Recorded uses of trees on farm were primarily fuelwood for household consumption and timber for income generation and household consumption. Fuelwood was ranked second in importance to timber despite the daily usage of firewood. Timber is considered the most important use due to the possibility of commercialisation with relatively good economic returns, compared to the returns from fuelwood and fruits. The demand for firewood is high but selling firewood was considered less important because of very low income from this activity. Firewood was particularly ranked higher in lower elevated areas where it is not readily available and timber production is less practical with low economic rewards. This suggests that changes in local environmental conditions, even over short distances, can significantly determine farming systems and livelihood strategies. The use of trees for construction material was ranked third, presumably, because shelter is an existential need, and because of the high demand and ease of selling construction material. Buying construction material is a major expense for the household, which can be avoided if construction material is readily available on farm. Fruit trees, without considering banana, play an important role for household consumption and commercialization. Altogether, the benefits of trees recorded in this study reflect those documented in Western Kenya (Thorlakson and Neufeldt 2012) and Eastern Kenya (Quandt et al. 2017). The authors found that farmers derive a variety of livelihood and environmental benefits by integrating trees in their farms thereby improving food security, income, farm productivity and environmental sustainability (Thorlakson and Neufeldt 2012; Quandt et al. 2017). Only regulating and supporting ecosystem services identified in two previous studies were not captured in this study. Farmers did not mention "indirect benefits" such as flood regulation, wind regulation, soil erosion control etc. in the survey. The reason might lie in the formulation and translation of survey questions that did not specifically ask for "indirect benefits".

The different tree species composition and diversity and their arrangement within the farm indicate possible extraction of different uses and benefits. Previously, studies have shown that socio-economic needs of households affect the diversity of perennial plants grown on farms in western Kenya (Scherr 1995; Henry et al. 2009). The list of the most frequently mentioned trees on-farm reflects farmers' preference of species rather than abundance, as the list of the most abundant trees generated from the tree inventory did not reveal the same order of species. The investigation discovered that timber and fruit trees have a very high value for farmers since they are the most wanted species and correlate positively with use and are mentioned most frequently by farmers. A high variety of different uses 
per tree species is important, since correlation analysis confirmed that less off-farm products need to be accessed when on-farm use is high. Interestingly, farmers in western Kenya seem to prefer exotics to native species. A similar trend was reported from the coffee agroforestry landscape of the Western Ghats, India where farmer's preference to G. robusta is driven by economic and legal advantages conferred to it (Nath et al. 2016).

Although the results suggest that measured socioeconomic factors do not determine on-farm carbon stocks, it is evident farmers' choices influence carbon stocks. It was evident, that also trees, similar to livestock, can serve the purpose as an investment and resource for the future, for example to pay school fees or to have construction material available for household expansion. The landscape of the study area has been greatly modified by farming practices and livelihood strategies. Native species are replaced by intentional planting of exotic species which grow fast and serve very specific on-farm uses such as timber, construction material, fruits or fodder. Further, grazing livestock probably influence tree growth and ultimately carbon stocks. We found that high on-farm carbon stocks are determined by the existence of woodlots but also influenced by farm elevation. Farms in higher elevated areas have fewer livestock and more carbon, while farms in lower areas have more livestock and less carbon. Livestock affect the structure and composition of trees through browsing and trampling. Protracted browsing eliminates palatable species, allowing those species that are less palatable to dominate the landscape.

\section{Conclusions}

Farmers of Kisumu County in Western Kenya practice six main types of agroforestry by maintaining and planting a diverse array of tree species for various uses and benefits; the trees support climate protection through carbon sequestration. Similar to previous work on carbon sequestration in similar smallholder farming systems, we found that the type of agroforestry practice (e.g. on-farm land use) and farm size, not species diversity, determines total farm carbon stock and benefits derived for the household. Carbon stocks are also driven by the number and the average size of trees on farm. Exotic timber species, mainly Eucalyptus, are the most abundant trees, suggesting a shift in landscape where native species are being replaced by exotics because of quick economic benefits. Understanding the drivers of tree selection can help meet both local food and fuel and global climate regulation needs. We recommend valorisation of the benefits provided by trees in agroforestry to determine perceived market benefits or realized economic benefits of native compared to exotic species. This will help establish general trade-offs or cobenefits of on-farm carbon stocks from economic values of benefits derived from trees.

Acknowledgements We thank the farmers of Nyando for opening their farms and homes to our inquiries. This work was implemented as part of the CGIAR Research Program on Climate Change, Agriculture and Food Security (CCAFS)'s Standard Assessment of Mitigation Potential and Livelihoods in Smallholder Systems Project (SAMPLES), which is carried out with support from the CGIAR Trust Fund and through bilateral funding agreements. For details please visit http://ccafs.cgiar. org/donors. The views expressed in this document cannot be taken to reflect the official opinions of these organizations. Shem Kuyah acknowledges the support of Alexander von Humboldt Foundation through the International Climate Protection Fellowship. He also acknowledges his host Prof. E. Luedeling, and the enabling environment enjoyed at the Institute of Crop Sciences and Resource Conservation (INRES)_-Horticultural Science.

Open Access This article is distributed under the terms of the Creative Commons Attribution 4.0 International License (http:// creativecommons.org/licenses/by/4.0/), which permits unrestricted use, distribution, and reproduction in any medium, provided you give appropriate credit to the original author(s) and the source, provide a link to the Creative Commons license, and indicate if changes were made. 
Appendix 1: Tree species documented on farms in Lower Nyando, Western Kenya

\begin{tabular}{|c|c|c|c|c|}
\hline Species & NO & $\mathrm{DBH}(\mathrm{cm})$ & Carbon (Mg) & Abundance $(\%)$ \\
\hline Eucalyptus spp. & 1849 & $7.74 \pm 6.16$ & 29.638 & 21.22 \\
\hline Vachellia spp.* & 833 & $5.61 \pm 3.51$ & 4.779 & 9.56 \\
\hline Euphorbia tirucalli & 660 & $5.88 \pm 3.64$ & 4.123 & 7.58 \\
\hline Grevillea robusta & 550 & $9.17 \pm 6.04$ & 10.486 & 6.31 \\
\hline Balanites aegyptiaca & 435 & $9.41 \pm 6.39$ & 9.300 & 4.99 \\
\hline Terminalia brownii & 389 & $8.88 \pm 6.00$ & 7.038 & 4.47 \\
\hline Rhus vulgaris & 385 & $5.46 \pm 3.37$ & 1.964 & 4.42 \\
\hline Thevetia peruviana & 385 & $4.66 \pm 2.69$ & 1.313 & 4.42 \\
\hline Euclea divinorum & 367 & $4.56 \pm 2.34$ & 1.028 & 4.21 \\
\hline Cupressus lusitanica & 356 & $10.43 \pm 6.03$ & 8.232 & 4.09 \\
\hline Leucaena leucocephala & 342 & $6.41 \pm 4.03$ & 2.638 & 3.93 \\
\hline Vepris nobilis & 242 & $5.96 \pm 4.09$ & 1.738 & 2.78 \\
\hline Grewia mollis & 211 & $6.83 \pm 4.24$ & 1.850 & 2.42 \\
\hline Markhamia lutea & 211 & $6.07 \pm 4.00$ & 1.497 & 2.42 \\
\hline Senna siamea & 170 & $6.77 \pm 3.96$ & 1.383 & 1.95 \\
\hline Psidium guajava & 131 & $5.07 \pm 2.36$ & 0.438 & 1.50 \\
\hline Sesbania sesban & 90 & $5.04 \pm 2.61$ & 0.321 & 1.03 \\
\hline Croton megalocarpus & 84 & $6.75 \pm 3.67$ & 0.631 & 0.96 \\
\hline Combretum molle & 79 & $5.68 \pm 3.81$ & 0.485 & 0.91 \\
\hline Croton macrostachyus & 74 & $10.45 \pm 8.05$ & 2.306 & 0.85 \\
\hline Jacaranda mimosifolia & 62 & $9.19 \pm 7.66$ & 1.628 & 0.71 \\
\hline Mangifera indica & 57 & $21.26 \pm 10.80$ & 6.898 & 0.65 \\
\hline Vangueria madagascariensis & 55 & $4.47 \pm 2.03$ & 0.134 & 0.63 \\
\hline Bridelia micrantha & 50 & $12.60 \pm 6.99$ & 1.747 & 0.57 \\
\hline Casuarina equisetifolia & 50 & $8.29 \pm 7.50$ & 1.117 & 0.57 \\
\hline Rhus natalensis & 44 & $4.18 \pm 1.74$ & 0.086 & 0.51 \\
\hline Persea americana & 43 & $9.17 \pm 8.61$ & 1.270 & 0.49 \\
\hline Citrus lemon & 39 & $4.93 \pm 2.17$ & 0.117 & 0.45 \\
\hline Combretum collinum & 33 & $6.87 \pm 3.55$ & 0.247 & 0.38 \\
\hline Azadirachta indica & 31 & $14.63 \pm 8.89$ & 1.646 & 0.36 \\
\hline Ficus sur & 30 & $14.46 \pm 12.41$ & 2.330 & 0.34 \\
\hline Solanecio manii & 28 & $6.36 \pm 2.04$ & 0.137 & 0.32 \\
\hline Dovyalis caffra & 23 & $5.54 \pm 2.55$ & 0.092 & 0.26 \\
\hline Gliricidia sepium & 22 & $5.12 \pm 2.24$ & 0.071 & 0.25 \\
\hline Turraea robusta & 22 & $4.11 \pm 1.02$ & 0.034 & 0.25 \\
\hline Melia azedarach & 20 & $9.07 \pm 5.64$ & 0.337 & 0.23 \\
\hline Combretum fragrans & 19 & $5.10 \pm 3.19$ & 0.081 & 0.22 \\
\hline Parkinsonia aculeata & 19 & $6.36 \pm 2.63$ & 0.103 & 0.22 \\
\hline Albizia coriaria & 17 & $13.30 \pm 8.35$ & 0.746 & 0.20 \\
\hline Tamarindus indica & 16 & $10.03 \pm 6.08$ & 0.360 & 0.18 \\
\hline Carissa spinarum & 14 & $3.77 \pm 1.18$ & 0.019 & 0.16 \\
\hline Albizia gumifera & 11 & $9.25 \pm 5.85$ & 0.197 & 0.13 \\
\hline Annona squamosa & 10 & $4.83 \pm 1.78$ & 0.026 & 0.11 \\
\hline Olea europaea & 10 & $11.51 \pm 8.12$ & 0.330 & 0.11 \\
\hline
\end{tabular}




\begin{tabular}{|c|c|c|c|c|}
\hline Species & NO & $\mathrm{DBH}(\mathrm{cm})$ & Carbon (Mg) & Abundance (\%) \\
\hline Vangueria infausta & 10 & $5.83 \pm 3.05$ & 0.049 & 0.11 \\
\hline Catha edulis & 9 & $12.16 \pm 9.69$ & 0.388 & 0.10 \\
\hline Piliostigma thonningii & 9 & $6.51 \pm 0.63$ & 0.040 & 0.10 \\
\hline Terminalia mantaly & 7 & $24.05 \pm 7.17$ & 0.880 & 0.08 \\
\hline Harrisonia abyssinica & 6 & $5.11 \pm 1.96$ & 0.018 & 0.07 \\
\hline Jatropha spp. & 6 & $3.96 \pm 1.36$ & 0.009 & 0.07 \\
\hline Spathodea campanulata & 6 & $6.30 \pm 2.38$ & 0.030 & 0.07 \\
\hline Vernonia amygdalina & 6 & $5.68 \pm 3.37$ & 0.029 & 0.07 \\
\hline Ziziphus тисronata & 6 & $4.52 \pm 2.00$ & 0.014 & 0.07 \\
\hline Calliandra calothyrsus & 5 & $3.40 \pm 0.74$ & 0.005 & 0.06 \\
\hline Ficus sycomorus & 5 & $6.74 \pm 7.25$ & 0.071 & 0.06 \\
\hline Zanthoxylum gilletii & 5 & $9.86 \pm 4.71$ & 0.081 & 0.06 \\
\hline Albizia zygia & 4 & $3.72 \pm 0.90$ & 0.005 & 0.05 \\
\hline Aningeria adolfi-friderici & 4 & $4.98 \pm 1.05$ & 0.010 & 0.05 \\
\hline Dovyalis abyssinica & 4 & $7.12 \pm 4.96$ & 0.036 & 0.05 \\
\hline Lantana camara & 4 & $3.38 \pm 0.73$ & 0.004 & 0.05 \\
\hline Morus alba & 4 & $6.00 \pm 2.03$ & 0.017 & 0.05 \\
\hline Syzygium cumini & 4 & $14.14 \pm 3.93$ & 0.132 & 0.05 \\
\hline Tarchonanthus camphoratus & 4 & $5.59 \pm 2.24$ & 0.015 & 0.05 \\
\hline Cordia monoica & 3 & $3.49 \pm 0.54$ & 0.003 & 0.03 \\
\hline Erythrina abyssinica & 3 & $35.87 \pm 30.66$ & 1.636 & 0.03 \\
\hline Moringa oleifera & 3 & $5.96 \pm 3.70$ & 0.016 & 0.03 \\
\hline Oncoba routledgei & 3 & $8.09 \pm 3.95$ & 0.029 & 0.03 \\
\hline Punica granatum & 3 & $10.15 \pm 3.39$ & 0.045 & 0.03 \\
\hline Casimiroa edulis & 2 & $18.86 \pm 2.81$ & 0.123 & 0.02 \\
\hline Commiphora africana & 2 & $6.75 \pm 1.89$ & 0.010 & 0.02 \\
\hline Cussonia holstii & 2 & $21.96 \pm 25.21$ & 0.384 & 0.02 \\
\hline Dichrostachys cinerea & 2 & $17.97 \pm 1.91$ & 0.108 & 0.02 \\
\hline Syzygium guineense & 2 & $71.31 \pm 7.07$ & 3.268 & 0.02 \\
\hline Vitex doniana & 2 & $9.61 \pm 3.69$ & 0.026 & 0.02 \\
\hline Adansonia digitata & 1 & 24.76 & 0.119 & 0.01 \\
\hline Callistemon citrinus & 1 & 7.00 & 0.005 & 0.01 \\
\hline Cissus rotundifolia & 1 & 4.01 & 0.001 & 0.01 \\
\hline Ficus thonningii & 1 & 3.37 & 0.001 & 0.01 \\
\hline Hibiscus rosa-sinensis & 1 & 5.54 & 0.003 & 0.01 \\
\hline Manihot esculenta (wild) & 1 & 15.28 & 0.036 & 0.01 \\
\hline Prunus africana & 1 & 7.00 & 0.005 & 0.01 \\
\hline Ricinus communis & 1 & 5.32 & 0.003 & 0.01 \\
\hline Senna septemtrionalis & 1 & 7.68 & 0.007 & 0.01 \\
\hline
\end{tabular}

The number of individuals for each species (NO), mean diameter at breast height (DBH) \pm the standard error of the mean, total carbon per species, and the relative abundance $(\%)$ is presented. Carbon was determined from biomass using a factor of 0.47 (IPCC 2006 ). Aboveground biomass (AGB) was estimated using the equation, AGB $=0.0905 * \mathrm{DBH}^{2.4718}$ (Kuyah et al. 2012)

* The following species of the genus Vachellia (formerly under the genus Acacia) were recorded in Lower Nyando: Vachellia abyssinica (Acacia abyssinica), Vachellia drepanolobium (Acacia drepanolobium), Vachellia elatior (Acacia elatior), Vachellia lahai (Acacia lahai), Vachellia nilotica (Acacia nilotica), Vachellia seyal (Acacia seyal), and Vachellia xanthophloea (Acacia xanthophloea). All these species are native to Africa 


\section{Appendix 2: Validation of allometric equations}

\begin{tabular}{lclrcc}
\hline Species & No & Allometric equation & RE1 & RE2 & References \\
\hline Acacia spp. & 8 & $\exp (-1.59) * \mathrm{D}^{2.19}$ & 5.5 & 30.2 & Paul et al. (2013) \\
Bridelia Micrantha & 2 & $\exp (-1.996+2.32 * \mathrm{LN}(\mathrm{D}))$ & 1.0 & 22.7 & Brown (1997) \\
Combretum molle & 1 & $\exp (-1.996+2.32 * \mathrm{LN}(\mathrm{D}))$ & 18.0 & -4.5 & Brown (1997) \\
Croton Macrostachyus & 2 & $\exp (-1.996+2.32 * \mathrm{LN}(\mathrm{D}))$ & -6.4 & -57.4 & Brown (1997) \\
Cupressus lusitanica & 5 & $\exp (-1.996+2.32 * \mathrm{LN}(\mathrm{D}))$ & -4.8 & -11.8 & Brown (1997) \\
Eucalyptus spp & 45 & $\exp (-1.71) * \mathrm{D}^{2.21}$ & 6.3 & -5.5 & Paul et al. (2013) \\
Ficus spp. & 1 & $\exp (-1.996+2.32 * \mathrm{LN}(\mathrm{D}))$ & 43.9 & -53.8 & Brown (1997) \\
Grevillea robusta & 5 & $1.384 * \mathrm{D}^{1.665}$ & 35.9 & 43.4 & Owate et al. (2018) \\
Jacaranda mimosifolia & 2 & $\exp (-1.996+2.32 * \mathrm{LN}(\mathrm{D}))$ & 22.9 & 11.2 & Brown (1997) \\
Mangifera indica & 7 & $\exp (-1.996+2.32 * \mathrm{LN}(\mathrm{D}))$ & 12.3 & 13.5 & Brown (1997) \\
Markhamia lutea & 9 & $\exp (-1.996+2.32 * \mathrm{LN}(\mathrm{D}))$ & 2.3 & -61.4 & Brown (1997) \\
Persia americana & 2 & $\exp (-1.996+2.32 * \mathrm{LN}(\mathrm{D}))$ & 2.2 & -12.6 & Brown (1997) \\
Spathodea campanulata & 1 & $\exp (-1.996+2.32 * \mathrm{LN}(\mathrm{D}))$ & -18.0 & -131.4 & Brown (1997) \\
Syzygium cordatum & 4 & $\exp (-1.996+2.32 * \mathrm{LN}(\mathrm{D}))$ & 17.2 & 18.8 & Brown (1997) \\
\hline
\end{tabular}

Allometric equations for estimating biomass were tested using destructively sampled data from western Kenya. NO represents the number of trees used to validate the equation. The relative error (RE, \%) for the regional equation by Kuyah et al. (2012), $\mathrm{AGB}=0.0905 * \mathrm{D}^{2.4718}(\mathrm{RE} 1)$ and for species specific equations (RE2) was calculated as: RE $(\%)=[($ predicted biomass-actual biomass)/actual biomass] * 100. The equation for Brown (1997) for dry tropics was used when species specific equations were lacking. Only equations that met the criteria listed in the methods (see data analysis section) were selected. Emphasis was given to species that contributed most of individulas to the total number of trees recorded. Harvest data was not available to validate some species

\section{Appendix 3: List of the most frequently mentioned uses and benefits in the household (HH) survey}

\begin{tabular}{|c|c|c|c|c|c|}
\hline Rank & Uses and benefits & Description & $\begin{array}{l}\text { Tree } \\
\text { species }\end{array}$ & $\begin{array}{l}\mathrm{HH} \\
\text { mentions }\end{array}$ & Main species \\
\hline 1 & Firewood (FW) & $\begin{array}{l}\text { Obtained either by pruning and drying harvested } \\
\text { branches, by collecting dry fallen-off branches, or } \\
\text { selectively harvesting trees from woodlots }\end{array}$ & 68 & 57 & $\begin{array}{l}\text { Euc., Gre., Ter., Vep., } \\
\text { Rhu. }\end{array}$ \\
\hline 2 & $\begin{array}{l}\text { Construction } \\
\text { material }(\mathrm{CM})\end{array}$ & $\begin{array}{l}\text { Parts such as poles obtained from the entire stem of } \\
\text { young trees or from cut-offs from the stems of } \\
\text { bigger trees. Small branches and twigs are also used } \\
\text { for house construction (walling) }\end{array}$ & 40 & 52 & $\begin{array}{l}\text { Euc., Ter., Vep., Gre., } \\
\text { Cup. }\end{array}$ \\
\hline 3 & Shade (Sh) & $\begin{array}{l}\text { Trees that create shade are mostly appreciated on the } \\
\text { compound but also on other farm components }\end{array}$ & 56 & 36 & $\begin{array}{l}\text { Gre., The., Vep., Cro., } \\
\text { Aza. }\end{array}$ \\
\hline 4 & Timber (Ti) & $\begin{array}{l}\text { Timber is usually the processed wood often sold to a } \\
\text { customer at the farm or at a market. Usually the } \\
\text { owner of the tree is responsible for harvesting, } \\
\text { cutting and transportation }\end{array}$ & 23 & 33 & $\begin{array}{l}\text { Euc., Gre., Ter., Cup., } \\
\text { Cro. }\end{array}$ \\
\hline 5 & Fruits (Fr) & $\begin{array}{l}\text { Fruits from trees are valuable for home consumption } \\
\text { and for sale }\end{array}$ & 18 & 33 & $\begin{array}{l}\text { Man., Psi., Per., Cit., } \\
\text { Car. }\end{array}$ \\
\hline 6 & Charcoal (Ch) & Woodfuel is used for charcoal burning & 29 & 18 & $\begin{array}{l}\text { Vep., Eucl., Ter., } \\
\text { Cari., Psi. }\end{array}$ \\
\hline
\end{tabular}




\begin{tabular}{|c|c|c|c|c|c|}
\hline Rank & Uses and benefits & Description & $\begin{array}{l}\text { Tree } \\
\text { species }\end{array}$ & $\begin{array}{l}\mathrm{HH} \\
\text { mentions }\end{array}$ & Main species \\
\hline 7 & Medicine (Me) & Trees with medicinal values & 15 & 23 & $\begin{array}{l}\text { Aza., Mel., Vep., Eucl, } \\
\text { Cro. }\end{array}$ \\
\hline 8 & Live fencing (LF) & $\begin{array}{l}\text { Trees are planted and managed to act as a live fence } \\
\text { around animal shelters and homesteads for } \\
\text { protection }\end{array}$ & 20 & 13 & $\begin{array}{l}\text { The., Fre., Mel., Vep., } \\
\text { Crot. }\end{array}$ \\
\hline 9 & $\begin{array}{l}\text { Fencing material } \\
\quad(\mathrm{FM})\end{array}$ & $\begin{array}{l}\text { Material from trees useful for fencing. This can be } \\
\text { twigs, thorns, small sticks and branches, very often } \\
\text { for constructing animal shelters or for reinforcing } \\
\text { or building fences along boundaries }\end{array}$ & 13 & 12 & $\begin{array}{l}\text { Aca., Grew., Ter., } \\
\text { Bal., Mar. }\end{array}$ \\
\hline 9 & Fodder (Fo) & Leaves and branches, can be used as fodder & 12 & 15 & $\begin{array}{l}\text { Leu., Vep., Eucl., } \\
\text { Grew., Rhu. }\end{array}$ \\
\hline 10 & Sale (Sa) & $\begin{array}{l}\text { Trade involving a whole tree sale. The customer, } \\
\text { rather than the owner, is responsible for harvesting } \\
\text { and transportation }\end{array}$ & 6 & 7 & $\begin{array}{l}\text { Euc., Ter., Gre., Cas., } \\
\text { Cup. }\end{array}$ \\
\hline 11 & Green manure (GM) & Leaves are used as green manure & 5 & 7 & Gre. \\
\hline 11 & Tools (To) & $\begin{array}{l}\text { Stems, branches or leaves are used for tools such as } \\
\text { walking stick, toothbrush, hand plough and brooms }\end{array}$ & 7 & 7 & Cup. \\
\hline
\end{tabular}

Description, total number of tree species mentioned, the number of households citing the tree species and the five main species that deliver the use/benefit is presented

Euc: Eucalyptus saligna, Gre: Grevillea robusta, Ter: Terminalia brownii, Vep: Vepris nobilis, Rhu: Rhus vulgaris, Cup: Cupressus lusitanica, The: Thevetia peruviana, Cro: Croton megalocarpus, Aza: Azadirachta indica, Man: Mangifera indica, Psi: Psidium guajava, Per: Persea americana, Cit: Citrus lemon, Car: Carica papaya, Eucl: Euclea divinorum, Cari: Carissa spinarum, Mel: Melia azedarach, Crot: Croton macrostachyus, Aca: Acacia spp. Grew: Grewia mollis, Bal: Balanites eagyptica, Mar: Markhamia lutea, Leu: Leucaena leucocephala, Cas: Casuarina equisetifolia

\section{References}

Albrecht A, Kandji ST (2003) Carbon sequestration in tropical agroforestry systems. Agric Ecosyst Environ 99:15-27

Boye A, Verchot L, Zomer RJ (2008) Baseline report, yala and nzoia river basins. Western Kenya intergrated ecosystem management project. Findings from the baseline surveys

Bradley PN (1988) Survey farms of in biomass woody Western Kenya. Ambio 1:40-48

Brown S (1997) Estimating biomass and biomass change of tropical forests: a primer. Vol 134 of FAO Forestry Paper. Rome, Italy

Bryan E, Ringler C, Okoba B et al (2013a) Adapting agriculture to climate change in Kenya: household strategies and determinants. J Environ Manag 114:26-35. https://doi.org/ 10.1016/j.jenvman.2012.10.036

Bryan E, Ringler C, Okoba B et al (2013b) Can agriculture support climate change adaptation, greenhouse gas mitigation and rural livelihoods? Insights from Kenya. Clim Change 118:151-165. https://doi.org/10.1007/s10584012-0640-0

Dinesh D, Campbell BM, Bonilla-findji O, Richards M (2017) 10 Best bet innovations for adaptation in agriculture: a supplement to the UNFCCC NAP technical guidelines. Wageningen, The Netherlands

Dumont ES, Bonhomme S, Pagella TF, Sinclair FL (2017) Structured stakeholder engagement leads to development of more diverse and inclusive agroforestry options. Exp Agric. https://doi.org/10.1017/s0014479716000788

Faye MD, Weber JC, Abasse TA et al (2011) Farmers' preferences for tree functions and species in the West African Sahel. For Trees Livelihoods 20:113-136. https://doi.org/ 10.1080/14728028.2011.9756702

Gachuiri AN, Carsan S, Karanja E et al (2017) Diversity and importance of local fodder tree and shrub resources in mixed farming systems of central Kenya. For Trees Livelihoods 26:143-155. https://doi.org/10.1080/ 14728028.2017.1316216

Guillemot J, le Maire G, Munishamappa M et al (2018) Native coffee agroforestry in the Western Ghats of India maintains higher carbon storage and tree diversity compared to exotic agroforestry. Agric Ecosyst Environ 265:461-469. https:// doi.org/10.1016/j.agee.2018.06.002

Hall NM, Kaya B, Dick J et al (2005) Effect of improved fallow on crop productivity, soil fertility and climate-forcing gas emissions in semi-arid conditions. Biol Fertil Soils 42:224-230. https://doi.org/10.1007/s00374-005-0019-8

Harvey CA, Chacón M, Donatti CI et al (2014) Climate-smart landscapes: opportunities and challenges for integrating adaptation and mitigation in tropical agriculture. Conserv Lett 7:77-90. https://doi.org/10.1111/conl.12066

Henry M, Tittonell P, Manlay RJ et al (2009) Biodiversity, carbon stocks and sequestration potential in aboveground biomass in smallholder farming systems of western Kenya. 
Agric Ecosyst Environ 129:238-252. https://doi.org/10. 1016/j.agee.2008.09.006

IBM Corp (2011) IBM Corp. Released 2011. IBM SPSS statistics for Windows

Iiyama M, Neufeldt H, Dobie P et al (2014) The potential of agroforestry in the provision of sustainable woodfuel in sub-Saharan Africa. Curr Opin Environ Sustain 6:138-147. https://doi.org/10.1016/j.cosust.2013.12.003

IPCC (2006) Volume 4: agriculture, forestry and other land use. In: 2006 IPCC guidelines for national greenhouse gas inventories. Intergovernmental Panel on Climate Change (IPCC), IPCC/IGES, Hayama, Japan

IPCC (2014) Climate change 2014: synthesis report. In: Pachauri RK, Meyer LA (eds) Contribution of Working Groups I, II and III to the fifth assessment report of the intergovernmental panel on climate change. Intergovernmental Panel on Climate Change (IPCC), IPCC/IGES, Geneva, pp 1-112

Kindt R, Coe R (2005) Tree diversity analysis. A manual and software for common statistical methods for ecological and biodiversity studies. World Agroforestry Centre (ICRAF), Nairobi

Kindt R, Van Damme P, Simons AJ, Beeckman H (2006) Planning tree species diversification in Kenya based on differences in tree species composition between farms. II. Analysis of tree niches. Agrofor Syst 67:229-241. https:// doi.org/10.1007/s10457-005-3824-z

Kuyah S, Rosenstock TS (2015) Optimal measurement strategies for aboveground tree biomass in agricultural landscapes. Agrofor Syst 89:125-133. https://doi.org/10.1007/ s10457-014-9747-9

Kuyah S, Dietz J, Muthuri C et al (2012) Allometric equations for estimating biomass in agricultural landscapes: I. Aboveground biomass. Agric Ecosyst Environ 158:216-224. https://doi.org/10.1016/j.agee.2012.05.011

Kuyah S, Dietz J, Muthuri C et al (2013) Allometry and partitioning of above- and below-ground biomass in farmed eucalyptus species dominant in Western Kenyan agricultural landscapes. Biomass Bioenergy 55:276-284. https:// doi.org/10.1016/j.biombioe.2013.02.011

Kuyah S, Sileshi GW, Njoloma J et al (2014) Estimating aboveground tree biomass in three different miombo woodlands and associated land use systems in Malawi. Biomass Bioenergy 66:214-222. https://doi.org/10.1016/j. biombioe.2014.02.005

Magurran AE (2004) Measuring biological diversity, 1st edn. Blackwell Publishing, Oxford

Mango J, Mideva A, Osanya W, Odhiambo A (2011) Summary of baseline household survey results: lower Nyando, Kenya. World Agroforestry Centre (ICRAF). Nairobi, Kenya, pp 1-32

Marone D, Poirier V, Coyea M et al (2017) Carbon storage in agroforestry systems in the semi-arid zone of Niayes, Senegal. Agrofor Syst 91:941-954. https://doi.org/10. 1007/s10457-016-9969-0

Middendorp RS, Vanacker V, Lambin EF (2018) Impacts of shaded agroforestry management on carbon sequestration, biodiversity and farmers income in cocoa production landscapes. Landsc Ecol 33:1953-1974. https://doi.org/10. 1007/s10980-018-0714-0
Montagnini F, Nair P (2004) Carbon sequestration: An underexploited environmental benefit of agroforestry systems. Agrofor Syst 61:281-295

Morton JF (2007) The impact of climate change on smallholder and subsistence agriculture. Proc Natl Acad Sci 104:19680-19685

Nair PKR, Nair VD (2014) 'Solid-fluid-gas': the state of knowledge on carbon-sequestration potential of agroforestry systems in Africa. Curr Opin Environ Sustain 6:22-27. https://doi.org/10.1016/j.cosust.2013.07.014

Nath CD, Schroth G, Burslem DFRP (2016) Why do farmers plant more exotic than native trees? A case study from the Western Ghats, India. Agric Ecosyst Environ 230:315-328. https://doi.org/10.1016/j.agee.2016.05.013

Ogle SM, Olander L, Wollenberg L et al (2014) Reducing greenhouse gas emissions and adapting agricultural management for climate change in developing countries: providing the basis for action. Glob Change Biol 20:1-6. https://doi.org/10.1111/gcb.12361

Owate OA, Mware MJ, Kinyanjui MJ (2018) Allometric equations for estimating silk oak (Grevillea robusta) biomass in agricultural landscapes of Maragua Subcounty, Kenya. Int J Forest Res. https://doi.org/10.1155/2018/6495271

Paul KI, Roxburgh SH, England JR et al (2013) Development and testing of allometric equations for estimating aboveground biomass of mixed-species environmental plantings. For Ecol Manag 310:483-494. https://doi.org/10.1016/j. foreco.2013.08.054

Porter JR, Xie L, Challinor AJ et al (2014) Food security and food production systems. In: Field CB, Barrios VR, Dokken DJ et al (eds) Climate change 2014: impacts, adaptation, and vulnerability. Part A: Global and sectoral aspects. Contribution of Working Group II to the fifth assessment report of the intergovernmental panel on climate change. Cambridge University Press, Cambridge, pp 485-533

Quandt A, Neufeldt H, McCabe JT (2017) The role of agroforestry in building livelihood resilience to floods and drought in semiarid Kenya. Ecol Soc 22(3):10. https://doi. org/10.5751/ES-09461-220310

Rosenstock TS, Rufino MC, Butterbach-Bahl K, Wollenberg E (2013) Toward a protocol for quantifying the greenhouse gas balance and identifying mitigation options in smallholder farming systems. Environ Res Lett 8:021003. https://doi.org/10.1088/1748-9326/8/2/021003

Rufino MC, Quiros C, Boureima M, et al (2012) Developing generic tools for characterizing agricultural systems for climate and global change studies (IMPACTlite-phase 2). Copenhagen, Denmark

Scherr SJ (1995) Economic factors in farmer adoption of agroforestry: patterns observed in Western Kenya. World Dev 23:787-804. https://doi.org/10.1016/0305750X(95)00005-W

Scholes RJ, Palm CA, Hickman JE (2014) Agriculture and climate change mitigation in the developing world. CCAFS working paper no. 61. CGIAR research program on climate change, Agriculture and Food Security (CCAFS). Copenhagen, Denmark. Available online at: https://ccafs.cgiar. org/

Sileshi GW (2014) A critical review of forest biomass estimation models, common mistakes and corrective measures. 
For Ecol Manag 329:237-254. https://doi.org/10.1016/j. foreco.2014.06.026

Takimoto A, Nair PKR, Nair VD (2008) Carbon stock and sequestration potential of traditional and improved agroforestry systems in the West African Sahel. Agric Ecosyst Environ 125:159-166. https://doi.org/10.1016/j.agee. 2007.12.010

Thorlakson T, Neufeldt H (2012) Reducing subsistence farmers' vulnerability to climate change: evaluating the potential contributions of agroforestry in western Kenya. Agric Food Secur 1:15. https://doi.org/10.1186/2048-7010-1-15

Publisher's Note Springer Nature remains neutral with regard to jurisdictional claims in published maps and institutional affiliations. 